\title{
Pemanfaatan Jerami Kedelai pada Pakan Induk Sapi Silangan Simmental-Peranakan Ongole
}

\author{
The use of hay to feed the cow cruciferous soybean \\ simmental ongole descent \\ Batseba M.W. Tiro ${ }^{\#}$ dan Petrus A. Beding ${ }^{\#}$ \\ Balai Pengkajian Teknologi Pertanian Papua \\ Jl. Yahim Sentani, Jayapura-Papua
}

\begin{abstract}
The onset of first postpartum estrous is an indicator in the beef cattle reproduction efficiency. Soybean straw is a local feed ingredients that contain phytoestrogen compounds. The present experiment was conducted to determine the effect of the use of soybean straw as a source of phytoestrogen to accelerate the onset of the first postpartum estrous of Simmental - Ongole crossbred cows. This research applies by completely randomized design (CRD) consisted three treatments and each treatment is repeated five times. Treatment consist of : P0: control (standar feed), P1: control $+5 \mathrm{~g}$ of phytoestrogen $(1.8 \mathrm{~kg}$ of soybean straw), and P2: control +10 of g phytoestrogen $(3.6 \mathrm{~kg}$ of soybean straw). The result showed that the use of soybean straw as a source of phytoestrogen increase consumption $\mathrm{CP}(\mathrm{P}<0,05)$, whereas DM and TDN comsumption increased only slighthy $(P>0,05)$. Supplementation of soybean straw as a source phytoestrogen are also likely to accelerate the first postpartum estrous.
\end{abstract}

Key Words: Soybean straw, Phytoestrogen, Feed, First estrous, Postpartum

\section{PENDAhuluan}

Dalam upaya untuk mencapai target kecukupan daging sapi, salah satu kebijakan pemerintah pada sub sektor peternakan adalah perbaikan mutu genetik sapi, dengan mengawinkan sapi potong lokal (Peranakan Ongole/PO) menggunakan semen Simmental maupun Limousin. Keturunan hasil silangan ini disebut dengan sapi silangan Simmental - PO (SimPO) dan silangan Limousin - PO (LimPO), (Hardjosubroto, 2004). Saat ini, peternak peternak cenderung memilih sapi SimPO karena berat lahir yang lebih besar, pertumbuhan lebih cepat dan ukuran dewasa tubuh lebih cepat. Dilain pihak, kenyataan di lapangan menunjukkan bahwa pada induk sapi silangan estrus pertama pasca beranak panjang, jumlah inseminasi per kebuntingan (S/C) lebih tinggi, kawin berulang dan kejadian endometritis cukup tinggi (Putro, 2009b; Subarsono, 2009).

Kegiatan untuk meningkatkan produksi sapi potong terkendala antara lain oleh rendahnya kinerja reproduksi induk sapi potong. Disebabkan antara lain masih terlalu panjangnya jarak beranak (calving interval) yang mencapai 20 bulan atau lebih dan rendahnya angka kelahiran ternak yang hanya $21 \%$ dengan mortalitas pedet 18\% (Winugroho, 2002). Jarak beranak yang panjang merupakan kendala inefisiensi produktivitas sapi potong di Indonesia, dimana penyebab utamanya adalah akibat panjangnya estrus pertama pasca beranak, sebagai akibat balans energi negatif selama periode menyusui, defisiensi protein maupun defisiensi hormon gonadotropin. Sapi yang mengalami keterlambatan estrus pertama pasca beranak umumnya mempunyai skor kondisi tubuh (body condition score) rendah, kurang dari 2,5 serta biasanya mempunyai ovaria yang mengalami hipofungsi (ovaria hypofunction) (Putro, 2009a).

Salah satu dugaan yang menjadi penyebab panjangnya estrus pertama pasca beranak adalah karena faktor ketidak seimbangan hormon-hormon reproduksi primer seperti follicle stimulating hormone (FSH), luteinizing hormone ( $\mathrm{LH})$, estrogen dan progesteron. Di lapangan dijumpai banyak kasus terkait dengan dugaan adanya ketidak seimbangan hormon-hormon reproduksi yang kemudian menimbulkan masalah panjangnya estrus pertama pasca beranak. 
Selama ini usaha yang dilakukan untuk mempercepat estrus pertama pasca beranak adalah dengan penyuntikan Gonadotropin Releasing Hormone (GnRH), dimana GnRH ini distimulir oleh estrogen. Penyuntikan GnRH ini dimaksudkan untuk memacu segera aktivitas ovarium yang berperan penting dalam menentukan ovulasi pertama pasca beranak dengan munculnya estrus. Namun karena penyuntikan GnRH ini relatif mahal maka perlu dicari solusinya dengan memanfaatkan estrogen alami yang berasal dari tanaman atau yang dikenal dengan fitoestrogen. Fitoestrogen merupakan suatu senyawa estrogen pada tanaman. Estrogen sendiri merupakan hormon yang sangat berperan dalam menjaga fertilitas, termasuk fertilitas induk sapi tentunya. Informasi mengenai penggunaan fitoestrogen di Indonesia belum banyak bahkan mungkin belum pernak diungkap.

Fitoestrogen terdapat pada banyak tanaman legum (Adams, 1995). Beberapa tanaman legum yang dilaporkan memiliki kandungan fitoestrogen diantaranya adalah alfafa (Medicago sativa), semanggi putih (Trifolium repens), semanggi merah (Trifolium pratense), kedelai (Glycine sp.). Fitoestrogen sangat dikenal dan terkandung terutama dalam biji kedelai atau Glycine soja dan berbagai tanaman leguminosa yang lain (Jefferson et al., 2007). Fransworth et al. (1975) disitasi Groot (2004), melaporkan bahwa ada lebih dari 300 jenis tanaman yang teridentidikasi memiliki cukup aktivitas estrogen untuk memicu terjadinya estrus pada ternak.

Senyawa estrogenik, termasuk fitoestrogen dalam dosis kecil mempunyai pengaruh pada inisiasi pembebasan GnRH dari hipotalamus, memacu kelenjar pituitari anterior untuk membebaskan FSH dan LH, (Goff, 2004). Pendapat ini menunjukkan bahwa fitoestrogen dapat digunakan untuk mempercepat tercapainya estrus pertama pasca beranak dan proses ovulasi. Cepat timbulnya siklus estrus dan ovulasi pasca beranak, secara langsung akan dapat memperpendek jarak beranak.

Hasil penelitian terdahulu melaporkan bahwa jerami kedelai mengandung fitoestrogen 1,748 g/100 g (Tiro et al., 2010). Oleh karena itu dirasa perlu untuk dilakukan penelitian pemanfaatan jerami kedelai sebagai pakan ternak.

Penelitian bertujuan untuk mengetahui pengaruh penggunaan jerami kedelai sebagai sumber fitoestrogen untuk memperpendek estrus pertama pasca beranak induk sapi SimPO.

\section{MATERI DAN METODA}

Penelitian dilaksanakan di kandang percobaan Laboratoriukm Ternak Potong, Kerja dan Kesayangan, Fakultas Peternakan, Universitas Gadjah Mada. Menggunakan 15 ekor induk sapi SimPO pasca beranak (kisaran umur 3 - 4 tahun dan sudah 2 - 3 kali beranak) dengan bobot badan awal bervariasi antara 350 sampai $500 \mathrm{~kg}$, dan rataan bobot badan awal $414 \pm 13,07 \mathrm{~kg}$.

Induk sapi dipelihara sejak \pm 3 bulan terakhir masa kebuntingan dengan maksud agar manajemen pemeliharaan (pakan dan perkandangan) sebelum penelitian dimulai adalah sama sehingga mengurangi bias pada saat pelaksanaan penelitian. Segera setelah beranak, ternak diacak untuk dimasukkan dalam perlakuan, kemudian diberikan obat cacing Valbendazol dan vitamin A, D dan E. Induk sapi diberi pakan standar terdiri dari hijauan dan konsentrat (60\% : 40\%), dengan kandungan PK $11 \%$ dan TDN $60 \%$. Hijauan yang digunakan adalah rumput gajah (Pennisetum purpureum). Bahan pakan yang digunakan dalam penelitian dianalisis secara proksimat (AOAC, 2005). Kandang yang digunakan adalah kandang individu yang dilengkapi dengan tempat pakan dan minuman.

Penelitian ini menggunakan rancangan acak lengkap (RAL) yang terdiri atas 3 perlakuan dan masing-masing perlakuan diulang 5 kali.

Adapun perlakuan suplementasinya adalah sebagai berikut :

P0 : kontrol (hanya diberi pakan basal)

$\mathrm{P} 1 \quad: \mathrm{P} 0+5 \mathrm{~g}$ fitoestrogen (setara dengan 1,8 $\mathrm{kg}$ jerami kedelai)

P2 : P0 + $10 \mathrm{~g}$ fitoestrogen (setara dengan 3,6 $\mathrm{kg}$ jerami kedelai)

Pemberian $5 \mathrm{~g}$ fitoestrogen setara dengan $1,8 \mathrm{~kg}$ jerami kedelai dan pemberian fitoestrogen $10 \%$ setara dengan 3,6 kg jerami kedelai setelah diperhitungkan dengan kecernaan BK jerami kedelai sebesar 58\%. Jerami kedelai diberikan terlebih dahulu hingga habis dikonsumsi dilanjutkan dengan pemberian konsentrat dan dan rumput gajah. 
Batseba M.W. Tiro dan Petrus A. Beding.Pemanfaatan Jerami Kedelai pada Pakan Induk Sapi Silangan Simmental-Peranakan Ongole

Konsentrat dan hijauan diberikan dua kali sehari yaitu pada pagi dan sore hari. Komposisi kimia bahan pakan penelitian tercantum pada Tabel 1 .

TABEL 1. KOMPOSISI KIMIA BAHAN PAKAN PENELITIAN

\begin{tabular}{|c|c|c|c|c|c|c|c|}
\hline \multirow{2}{*}{$\begin{array}{c}\text { Nama/ Kode } \\
\text { Bahan (as fed) }\end{array}$} & \multirow{2}{*}{$\begin{array}{c}\text { Baha } \\
\text { n } \\
\text { Keri } \\
\text { ng } \\
(\%)^{1}\end{array}$} & \multicolumn{5}{|c|}{ Kadar (\% DM Basis) } & \multirow[b]{2}{*}{$\begin{array}{l}\mathrm{TD} \\
\mathrm{N}^{2}\end{array}$} \\
\hline & & $\underset{1}{\mathrm{Abu}}$ & $\begin{array}{c}\text { Prote } \\
\text { in } \\
\text { Kasa } \\
\mathrm{r}^{1}\end{array}$ & $\begin{array}{c}\text { Lem } \\
\text { ak } \\
\text { Kasa } \\
r^{1}\end{array}$ & $\begin{array}{c}\text { Serat } \\
\text { Kasa } \\
r^{1}\end{array}$ & $\begin{array}{l}\text { BET } \\
\mathrm{N}^{1}\end{array}$ & \\
\hline Rumput gajah & $\begin{array}{c}20,7 \\
8\end{array}$ & $\begin{array}{c}14,5 \\
6\end{array}$ & 10,9 & 2,04 & $\begin{array}{c}33,8 \\
4\end{array}$ & 38,66 & $\begin{array}{c}53,7 \\
1\end{array}$ \\
\hline Jerami kedelai & $\begin{array}{c}28,1 \\
4\end{array}$ & 9,41 & 14,45 & 2,78 & $\begin{array}{c}33,2 \\
2\end{array}$ & 40,14 & $\begin{array}{c}53,6 \\
4\end{array}$ \\
\hline \multicolumn{8}{|l|}{ Konsentrat : } \\
\hline $\begin{array}{ll}\text { - } & \text { Dedak } \\
& \text { halus }\end{array}$ & $\begin{array}{c}90,8 \\
9\end{array}$ & $\begin{array}{c}16,9 \\
6\end{array}$ & 5,79 & 1,85 & $\begin{array}{c}31,2 \\
9\end{array}$ & 56,88 & $\begin{array}{c}45,1 \\
2\end{array}$ \\
\hline - $\quad$ Bran & $\begin{array}{c}87,0 \\
4\end{array}$ & 5,29 & 12,56 & 3,19 & $\begin{array}{c}10,6 \\
7\end{array}$ & 68,29 & $\begin{array}{c}71,3 \\
6\end{array}$ \\
\hline $\begin{array}{ll}\text { - } & \text { Bungki } \\
1 \\
\text { kelapa } \\
\text { sawit }\end{array}$ & $\begin{array}{c}91,4 \\
1\end{array}$ & 3,71 & 13,21 & $\begin{array}{c}12,7 \\
5\end{array}$ & $\begin{array}{c}13,4 \\
5\end{array}$ & 56,88 & $\begin{array}{c}53,7 \\
1\end{array}$ \\
\hline
\end{tabular}

Sumber : 1. Hasil analisa proksimat Laboratorium Bagian Nutrisi dan Makanan ternak, Fakultas Peternakan, Universitas Gadjah Mada.

2. Hasil hitungan dengan rumus Hartadi et al. (2005).

\section{Parameter yang diamati}

Parameter yang diamati meliputi konsumsi pakan dan periode timbulnya estrus pertama pasca beranak induk sapi SimPO. Pengumpulan data konsumsi pakan dilakukan setiap hari dan merupakan selisih antara pakan pemberian dan pakan yang tersisa dalam waktu 24 jam. Tiap induk diamati 4 kali atau lebih pada tiap harinya untuk mengetahui kapan terjadinya estrus melaluigejalagejala yang nampak seperti perubahan tingkah laku dan tanda-tanda luar (Sturman et al., 2000). Pengamatan secara teliti dilakukan setiap hari pada pukul 06.00; 12.00; 18.00 dan 24.00. Estrus merupakan fase saat hewan diam saja kalau dinaiki oleh hewan lain (standing estrus), mengeluarkan leleran mukus dari vulva dengan konduktivitas spesifik (Sawyer et al., 1990) dan dianggap hari 0 dari siklus terbaru.

Data dianalisis menggunakan Sidik Ragam dan bila perlakuan menunjukkan pengaruh yang signifikan dilanjutkan dengan uji Duncan (Steel dan Torrie, 1989).

\section{HASIL DAN PEMBAHASAN Konsumsi Pakan}

Rataan konsumsi bahan kering (BK), protein kasar (PK) dan TDN induk sapi SimPO pasca beranak terlihat pada Tabel 2. Berdasarkan data pada Tabel 2, terlihat bahwa terjadi peningkatan konsumsi baik itu konsumsi PK dengan adanya suplementasi jerami kedelai $(\mathrm{P}<0,05)$, sedangkan konsumsi BK dan TDN hanya sedikit mengalami peningkatan $(\mathrm{P}>0,05)$.

TABEL 2. RATAAN KONSUMSI BK, PK DAN TDN INDUK SAPI SIMPO

\begin{tabular}{|c|c|c|c|c|}
\hline \multicolumn{2}{|r|}{ Uraian } & \multicolumn{3}{|c|}{ Perlakuan } \\
\hline & & PO & PI & PII \\
\hline \multirow[t]{4}{*}{1.} & $\begin{array}{l}\text { Konsumsi BK } \\
\left(^{(k g / \text { ekor/hari) }}{ }^{\text {ns }}\right.\end{array}$ & $\begin{array}{c}11,06 \pm \\
0,42\end{array}$ & $\begin{array}{c}11,50 \pm \\
0,09\end{array}$ & $\begin{array}{c}11,99 \pm \\
0,13\end{array}$ \\
\hline & - Rumput gajah & $\begin{array}{c}6,26 \pm \\
0,39\end{array}$ & $\begin{array}{c}6,02 \pm \\
0,03\end{array}$ & $\begin{array}{c}6,01 \pm \\
0,04\end{array}$ \\
\hline & - Jerami kedelai & - & $\begin{array}{c}0,51 \pm \\
0,00\end{array}$ & $\begin{array}{c}1,01 \pm \\
0,00\end{array}$ \\
\hline & Konsentrat & $\begin{array}{c}4,80 \pm \\
0,19\end{array}$ & $\begin{array}{c}4,98 \pm \\
0,10\end{array}$ & $\begin{array}{c}4,97 \pm \\
0,10\end{array}$ \\
\hline \multirow[t]{4}{*}{2.} & $\begin{array}{l}\text { Konsumsi } \\
\text { PK(kg/ekor/hari) }\end{array}$ & $\begin{array}{c}1,04 \pm \\
0,04\end{array}$ & $\begin{array}{c}1,12 \pm \\
0,01\end{array}$ & $\begin{array}{c}1,19 \pm \\
0,01\end{array}$ \\
\hline & - Rumput gajah & $\begin{array}{c}0,52 \pm \\
0,03\end{array}$ & $\begin{array}{c}0,50 \pm \\
0,00\end{array}$ & $\begin{array}{c}0,50 \pm \\
0,00\end{array}$ \\
\hline & - Jerami kedelai & - & $\begin{array}{c}0,07 \pm \\
0,00\end{array}$ & $\begin{array}{c}0,15 \pm \\
0,00\end{array}$ \\
\hline & - $\quad$ Konsentrat & $\begin{array}{c}0,52 \pm \\
0,02\end{array}$ & $\begin{array}{c}0,54 \pm \\
0,01\end{array}$ & $\begin{array}{c}0,54 \pm \\
0,01\end{array}$ \\
\hline \multirow[t]{4}{*}{3.} & $\begin{array}{l}\text { Konsumsi TDN } \\
\text { (kg/ekor/hari }^{\mathrm{ns}}\end{array}$ & $\begin{array}{c}7,50 \pm \\
0,25\end{array}$ & $\begin{array}{c}7,80 \pm \\
0,08\end{array}$ & $\begin{array}{c}8,06 \pm \\
0,10\end{array}$ \\
\hline & - Rumput gajah & $\begin{array}{c}3,36 \pm \\
0,21\end{array}$ & $\begin{array}{c}3,24 \pm \\
0,02\end{array}$ & $\begin{array}{c}3,23 \pm \\
0,02\end{array}$ \\
\hline & - Jerami kedelai & - & $\begin{array}{c}0,27 \pm \\
0,00\end{array}$ & $\begin{array}{c}0,54 \pm \\
0,00\end{array}$ \\
\hline & - Konsentrat & $\begin{array}{c}4,14 \pm \\
0,16\end{array}$ & $\begin{array}{c}4,37 \pm \\
0,09\end{array}$ & $\begin{array}{c}4,28 \pm \\
0,09\end{array}$ \\
\hline 4. & $\begin{array}{l}\text { Konsumsi BK } \\
\left(\mathrm{kg} / \mathrm{kgW}^{0,75}\right)^{\mathrm{ns}}\end{array}$ & $\begin{array}{c}0,12 \pm \\
0,00\end{array}$ & $\begin{array}{c}0,12 \pm \\
0,00\end{array}$ & $\begin{array}{c}0,13 \pm \\
0,00\end{array}$ \\
\hline 5. & $\begin{array}{l}\text { Konsumsi PK } \\
\left(\mathrm{kg} / \mathrm{kgW}^{0,75}\right)^{\mathrm{ns}}\end{array}$ & $\begin{array}{c}0,01 \pm \\
0,00\end{array}$ & $\begin{array}{c}0,01 \pm \\
0,00\end{array}$ & $\begin{array}{c}0,01 \pm \\
0,00\end{array}$ \\
\hline 6. & $\begin{array}{l}\text { Konsumsi TDN } \\
\left(\mathrm{kg} / \mathrm{kgW}^{0,75}\right)^{\mathrm{ns}}\end{array}$ & $\begin{array}{c}0,08 \pm \\
0,00\end{array}$ & $\begin{array}{c}0,08 \pm \\
0,00\end{array}$ & $\begin{array}{c}0,09 \pm \\
0,00\end{array}$ \\
\hline
\end{tabular}

Keterangan : ${ }^{\mathrm{ns}}=$ berpengaruh tidak nyata $(\mathrm{P}>$ $0,05)$

$*)$ = berpengaruh nyata $(\mathrm{P}<0,05)$

Total konsumsi BK pada perlakuan kontrol (P0) sebesar 11,06 $\pm 0,42 \mathrm{~kg} / \mathrm{ekor} /$ hari ; P1 sebesar $11,50 \pm 0,09 \mathrm{~kg} / \mathrm{ekor} /$ hari dan $\mathrm{P} 2$ sebesar 11,99 \pm $0,13 \mathrm{~kg} / \mathrm{ekor} / \mathrm{hari}$. Hasil analisa statistik, menunjukkan bahwa konsumsi BK, tidak dipengaruhi oleh perlakuan kecuali hanya terjadi sedikit penurunan konsumsi BK rumput gajah pada perlakuan P1 dan P2 (Tabel 2). Hal ini disebabkan ternak sudah terlebih dahulu mengkonsumsi jerami kedelai baru diberikan hijauan (rumput gajah), sehingga ternak akan mengurangi konsumsi hijauannya.

Rataan konsumsi PK pada perlakuan P0 sebesar 1,04 \pm 0,04 kg/ekor/hari; P1 sebesar 1,12 \pm 

$0,01 \mathrm{~kg} / \mathrm{ekor} / \mathrm{hari}$ dan $\mathrm{P} 2$ sebesar $1,19 \pm 0,01$ $\mathrm{kg}$ /ekor/hari. Analisis sidik ragam, menunjukkan ada pengaruh perlakuan $(\mathrm{P}<0,05)$ terhadap konsumsi $\mathrm{PK}$. Perlakuan suplementasi jerami kedelai memperlihatkan pengaruh yang nyata antar perlakuan $\mathrm{P} 0$ dengan perlakuan $\mathrm{P} 2$, juga antar $\mathrm{P} 1$ dan P2 $(\mathrm{P}<0,05)$, namun antara $\mathrm{P} 0$ dan $\mathrm{P} 1$ berpengaruh tidak nyata. Rataan konsumsi PK induk sapi SimPO dalam penelitian ini lebih tinggi (di atas $1 \mathrm{~kg}$ /ekor/hari), sedangkan rekomendasi NRC hanya sebesar $0,86 \mathrm{~kg}$ untuk induk sapi menyusui dengan berat badan $400 \mathrm{~kg}$. Oleh karena itu konsumsi PK dapat dikatakan sudah mencukupi kebutuhan induk sapi SimPO yang sedang menyusui.

Rataan konsumsi TDN untuk perlakuan P0 sebesar 7,50 \pm 0,25 kg/ekor/hari, P1 sebesar 7,80 \pm $0,08 \mathrm{~kg} / \mathrm{ekor} /$ hari dan $\mathrm{P} 2$ sebesar 8,06 $\pm 0,10$ $\mathrm{kg} /$ ekor/hari. Hasil analisis statistik, menunjukkan bahwa penggunaan jerami kedelai memperlihatkan pengaruh yang tidak nyata pada konsumsi TDN. Secara numerik, terjadi peningkatan konsumsi TDN dengan adanya suplementasi jerami kedelai. Peningkatan konsumsi PK dan TDN sejalan dengan konsumsi BKnya, karena konsumsi nutrien dipengaruhi oleh konsumsi BK dan kandungan nutrien pakan tersebut. Meningkatnya konsumsi BK maka akan berakibat pada kenaikan konsumsi nutrien lainnya.

Konsumsi BK, PK dan TDN per $\mathrm{kg} \mathrm{BB}^{0,75}$ menunjukkan perbedaan yang tidak nyata, dan berdasarkan berat badan metabolik konsumsi pakan relatif sama, hal ini menunjukkan bahwa perbedaan konsumsi pakan disebabkan oleh perbedaan berat badan.

\section{Estrus Pertama Pasca Beranak}

Pengamatan terhadap estrus pasca beranak dilakukan berdasarkan pengamatan tinglah laku yang diperkuat dengan palpasi rektal dan pemeriksaan USG untuk melihat diameter folikelnya. Pengamatan terhadap estrus pertama pasca beranak induk sapi SimPO terlihat pada Tabel 3.

TABEL 3. ESTRUS PERTAMA PASCA BERANAK INDUK SAPI

\begin{tabular}{ccc}
\multicolumn{2}{c}{ SIMPO } & \\
\hline \hline Perlakuan & Estrus & Gejala estrus \\
& pertama & \\
& pasca & \\
beranak & & \\
(hari) & \\
\end{tabular}

\begin{tabular}{|c|c|c|}
\hline P05 & 24 & $\begin{array}{l}\text { Melenguh-lenguh, vulva bengkak, } \\
\text { merah dan basah, diameter folikel } \\
12,0 \mathrm{~mm}\end{array}$ \\
\hline P04 & 95 & $\begin{array}{l}\text { Melenguh-lenguh, vulva bengkak, } \\
\text { merah dan basah, keluar lendir } \\
\text { bening dari vulva, diameter } \\
\text { folikel } 12,1 \mathrm{~mm}\end{array}$ \\
\hline P03 & 27 & $\begin{array}{l}\text { Melenguh-lenguh, vulva bengkak, } \\
\text { merah dan basah, diameter folikel } \\
13,0 \mathrm{~mm}\end{array}$ \\
\hline P02 & 40 & $\begin{array}{l}\text { Vulva bengkak, merah dan basah, } \\
\text { keluar lendir bening dari vulva }\end{array}$ \\
\hline P01 & 28 & $\begin{array}{l}\text { Vulva bengkak, merah dan basah, } \\
\text { keluar lendir bening dari vulva, } \\
\text { diameter folikel } 11,20 \mathrm{~mm}\end{array}$ \\
\hline Rataan & $\begin{array}{l}42,80 \pm \\
11,90^{\text {ns }}\end{array}$ & \\
\hline \multicolumn{3}{|l|}{ P1 } \\
\hline P11 & 29 & $\begin{array}{l}\text { Melenguh-lenguh, vulva bengkak, } \\
\text { merah dan basah, keluar lendir } \\
\text { bening dari vulva, diameter } \\
\text { folikel } 16,85 \mathrm{~mm}\end{array}$ \\
\hline P12 & 24 & $\begin{array}{l}\text { Melenguh-lenguh, vulva bengkak, } \\
\text { merah dan basah, keluar lendir } \\
\text { bening dari vulva, diameter } \\
\text { folikel } 11,75 \mathrm{~mm}\end{array}$ \\
\hline P13 & 41 & $\begin{array}{l}\text { Melenguh-lenguh, vulva bengkak, } \\
\text { merah dan basah, keluar lendir } \\
\text { bening dari vulva, diameter } \\
\text { folikel } 10,05 \mathrm{~mm}\end{array}$ \\
\hline P14 & 31 & $\begin{array}{l}\text { Melenguh-lenguh, vulva bengkak, } \\
\text { merah dan basah, keluar lendir } \\
\text { bening dari vulva, diameter } \\
\text { folikel } 11,25 \mathrm{~mm}\end{array}$ \\
\hline P15 & 24 & $\begin{array}{l}\text { Melenguh-lenguh, vulva bengkak, } \\
\text { merah dan basah, keluar lendir } \\
\text { bening dari vulva, diameter } \\
\text { folikel } 10,05 \mathrm{~mm}\end{array}$ \\
\hline Rataan & $\begin{array}{c}29,80 \pm \\
3,12^{\mathrm{ns}}\end{array}$ & \\
\hline \multicolumn{3}{|l|}{$\mathrm{P} 2$} \\
\hline P24 & 43 & $\begin{array}{l}\text { Melenguh-lenguh, vulva bengkak, } \\
\text { merah dan basah, keluar lendir } \\
\text { bening dari vulva,diameter folikel } \\
10,6 \mathrm{~mm}\end{array}$ \\
\hline P22 & 26 & $\begin{array}{l}\text { Melenguh-lenguh, vulva bengkak, } \\
\text { merah dan basah, keluar lendir } \\
\text { bening dari vulva, diameter } \\
\text { folikel } 11,45 \mathrm{~mm}\end{array}$ \\
\hline $\mathrm{P} 23$ & 21 & $\begin{array}{l}\text { Melenguh-lenguh, vulva bengkak, } \\
\text { merah dan basah, keluar lendir } \\
\text { bening dari vulva }\end{array}$ \\
\hline P25 & 20 & $\begin{array}{l}\text { Melenguh-lenguh, vulva bengkak, } \\
\text { merah dan basah, keluar lendir } \\
\text { bening dari vulva, diameter } \\
\text { folikel } 10,6 \mathrm{~mm}\end{array}$ \\
\hline P26 & 18 & $\begin{array}{l}\text { Melenguh-lenguh, vulva bengkak, } \\
\text { merah dan basah, keluar lendir } \\
\text { bening dari vulva, diameter } \\
\text { folikel } 13,0 \mathrm{~mm}\end{array}$ \\
\hline Rataan & $\begin{array}{l}25,60 \pm \\
4,54^{\mathrm{ns}}\end{array}$ & \\
\hline
\end{tabular}


Batseba M.W. Tiro dan Petrus A. Beding.Pemanfaatan Jerami Kedelai pada Pakan Induk Sapi Silangan Simmental-Peranakan Ongole

Hasil analisa statistik, menunjukkan bahwa suplementasi fitoestrogen berpengaruh tidak nyata terhadap estrus pertama pasca beranak, namun cenderung memperpendek tercapainya estrus pertama pasca beranak.

Data pada Tabel 3 menunjukkan bahwa rataan estrus pertama pasca beranak induk sapi SimPO pada perlakuan P0 (kontrol) adalah 42,80 \pm 11,90 hari dengan kisaran $24-95$ hari; perlakuan P1 (5 g fitoestrogen) adalah 29,80 $\pm 3,12$ hari dengan kisaran 24 - 41 hari dan perlakuan P2 $(10 \mathrm{~g}$ fitoestrogen) adalah 25,60 \pm 4,54 hari dengan kisaran 18 - 43 hari. Terlihat bahwa rataan estrus pertama pasca beranak induk sapi dengan adanya suplementasi fitoestrogen lebih pendek dibanding tanpa suplementasi fitoestrogen. Hal ini menunjukkan bahwa suplementasi fitoestrogen 5 dan $10 \mathrm{~g}$ dapat memperpendek estrus pertama pasca beranak.

Estrus pertama pasca beranak pada penelitian ini relatif jauh lebih pendek dibanding hasil penelitian Aryogi (2005), pada sapi PO dan SimPO adalah $119 \pm 0,62$ hari dan 117,18 $\pm 3,03$ hari, dan hasil penelitian Wijono dan Mariyono (2005) pada silangan Simmental dan PO pada pola peternak dan dengan perbaikan pakan adalah 143 hari dan 129 hari.

Lebih pendeknya estrus pertama pasca beranak dibanding hasil penelitian lainnya, selain disebabkan karena adanya suplementasi jerami kedelai juga karena penelitian dilakukan di stasiun percobaan sehingga pengamatan estrusnya lebih cermat dibandingkan penelitian di tingkat peternak. Post partum anestrus biasanya lebih sering terjadi pada sapi potong dibanding sapi perah dan post partum anestrus yang panjang (hingga 100 hari) biasa terjadi pada induk sapi yang masih menyusui.

Pada induk-induk sapi SimPO pasca beranak, gejala estrus pertama pasca beranaknya lemah atau kurang jelas sehingga harus betul-betul diamati supaya estrus pertamanya tidak terlewati. Berdasarkan pengamatan, gejala estrus yang selalu nampak pada induk-induk SimPO pasca beranak adalah melenguh-lenguh dan vulvanya bengkak, merah dan basah namun tidak semua induk mengeluarkan lendir bening seperti gejala estrus pada umumnya. Pada penelitian ini, untuk memastikan apakah induk tersebut memang benarbenar estrus maka diikuti dengan palpasi rektal dan pemeriksaan USG untuk melihat diameter folikel dominan. Akumulasi estrogen yang bersumber dari folikel dominan dan ovarium mempunyai kemampuan untuk mengaktualisasikan estrus pertama pasca beranak.

Penampilan gejala estrus pasca beranak yang lemah, disebabkan rendahnya konsentrasi estrogen yang terkandung dalam folikel dominan, walaupun estrogen tersebut mampu merangsang hipothalamus dan hipofisa anterior untuk menyekresikan LH untuk berlangsungnya ovulasi. Di samping itu, konsentrasi estrogen sangat bergantung pada gelombang folikel saat folikulogenesis berlangsung. FSH sangat penting dalam meningkatkan jumlah sel granulosa, kesinambungan pertumbuhan folikel dan perilaku estrus. Ukuran folikel dominan akan menentukan jumlah sel granulosa dan produksi estrogen (Fogwell, 1997 cit. Hadisusanto, 2008).

Hasil penelitian pada Tabel 3 juga menunjukkan bahwa dengan adanya suplementasi fitoestrogen, gejala-gejala estrusnya yang terlihat lebih jelas dibanding perlakuan tanpa suplementasi fitoestrogen (P0), dimana dari 5 ekor induk yang diamati ada 2 ekor induk yang mengalami estrus namun tidak disertai keluarnya lendir dari vulva. Hal ini memberikan gambaran bahwa fitoestrogen dapat lebih memperjelas gejala estrus yang muncul, karena fitoestrogen ini mampu menginisiasi pembebasan GnRH dari hipothalamus, dan memacu kelenjar pituitari anterior untuk membebaskan FSH dan LH. FSH adalah hormon yang diperlukan untuk folikulogenesis dan perkembangan folikel dominan untuk mensekresikan estrogen yang memadai bagi kemunculan gejala estrus pertama pasca beranak. Tingginya konsentrasi estrogen di dalam darah akan mempengaruhi peningkatan aliran darah ke organorgan genital dan memproduksi lendir oleh glandula di cervix dan vagina, ini semua merupakan tandatanda terjadinya estrus (Rasby and Vinton, 2008).

\section{IV.KESIMPULAN}

Penggunaan jerami kedelai sebagai sumber fitoestrogen hanya meningkatkan konsumsi PK dan cenderung mempercepat estrus pertama pasca beranak.

\section{DAFTAR PUSTAKA}

[1] Adams, N.R. 1995. Detection of the effects of phytoestrogens on sheep and cattle. 73 
[2] AOAC, 2005. Official Methods of Analysis. Association of Official Analytical Chemists. Editor: Horwitz, W. And G.W. Latimer, Jr. Pubished by AOAC International. 18 ${ }^{\text {th }}$ Edition. United States America.

[3] Aryogi, 2005. Kemungkinan Timbulnya Interaksi Genetik dan Ketinggian Lokasi terhadap Performan Sapi Potong Silangan Peranakan Ongole di Jawa Timur. Thesis. Program Pascasarjana Fakultas Peternakan Universitas Gadjah Mada. Yogyakarta.

[4] Goff, K. 2004. Steroid hormone modulation of prostaglandin secretion in the postpartum beef cows. Biology of Reproduction 71 : 11-16.

[5] Groot, M.J. 2004. Phyto - estrogenic activity of protein - rich feeds for pigs. RIKILT - Institute of Food Safety. 3-12.

[6] Gunawan, 2009. Rencana strategis kecukupan daging sapi tahun 2010-2014. Makalah disampaikan pada Seminar Nasional Pengembangan Ternak Potong untuk Mewujudkan Program Kecukupan/Swasembada Daging, dalam rangka Lustrum VIII Fakultas Peternakan UGM. Jogyakarta.

[7] Hadisutanto, B. 2008. Studi Tentang Beberapa Performaan Reproduksi Pada Berbagai Paritas Induk Dalam Formulasi Masa Kosong (Days Open) Sapi Perah Fries Holland. (Kasus pada Peternakan Rakyat di Kecamatan Lembang Kabupaten Bandung Barat). Disertasi. Program Pasca Sarjana. Institut Pertanian Bogor.

[8] Hardjosubroto, W. 2004. Aplikasi Pemuliabiakan Ternak di Lapangan. PT. Grasindo. Jakarta.

[9] Hartadi, H., S. Reksohadiprodjo dan A.D. Tillman. 2005. Tabel Komposisi Pakan Untuk Indonesia. Gadjah Mada University Press. Yogyakarta.

[10] Jefferson, W.N., E. Padilla-Banks, and R.R. Newbold. 2007. Disruption of the female reproductive system by the phytoestrogen genistein. Reproductive Toxicology 23 : 308-316.

[11] Putro, P.P. 2009a. Fenomena reproduksi sapi Brahman cross : permasalahan dan penanganannya. Makalah Evaluasi Pengadaan sapi Brahman Cross, Direktorat Perbibitan. Direktorat Jenderal Peternakan, Departemen Pertanian. Jakarta.

[12] Putro, P.P. 2009b. Dampak crossbreeding terhadap reproduksi induk turunannya: Hasil studi klinis. Makalah disampaikan pada Lokakarya Lustrum VIII Fakultas Peternakan, Universitas Gadjah Mada.

[13] Rasby, R.R. and R. Vinton. 2008. Estrous Cycle. Learning Module. University

of Nebraska.

http://www.nlm.nih.gov/medlineplus/ency/article/00 3718.htm.

(5 Mei 2011)

[14] Sawyer, G. J., P.E. Wiiliamson, A. Drajat, \& G. Howell. 1990. Detection of estrus by milk progesterone assay, visual observation and cervical mucus conductivity in estrus - synchroniced dairy cows. Proc. Austral. Soc. Anim. Prod. 18: 348-351.

[15] Steel, R.G.D. \& J.H. Torrie. 1989. Prinsip dan Prosedur Statistika. Suatu Pendekatan Biometrik. Penerbit PT Gramedia, Jakarta.

[16] Sturman, R. W., J.J. Brockway, \& A.P. Barry. 2000. Fixed time artificial insemination in Dairy cows. Theriogenology 49: 1338-1344.

[17] Subarsono, 2009. Dampak crossbreeding terhadap reproduksi induk turunannya : Pengalaman praktis di lapangan. Makalah disampaikan 8 Agustus 2009. pada Lokakarya Lustrum VIII Fakultas Peternakan, Universitas Gadjah Mada. Yogyakarta,

[18] Tiro, B.M.W., S. Pramono., H. Hartadi., D. Soetrisno \& E. Baliarti. 2010. The content of phytoestrogen of legume plants. International Seminar Tropical Animal Production. Yogyakarta, October 19 - 22, 2010. Faculty of Animal Science, Universitas Gadjah Mada Yogyakarta.

[19] Wijono, D.B. \& Mariyono. 2005. Review hasil penelitian model low external input di Loka Penelitian Sapi Potong tahun 2002-2004. Pros. Seminar Nasional Teknologi Peternakan dan Veteriner. Puslitbangnak. Bogor. Hal. 43-56.

[20] Winugroho, M. 2002. Strategi pemberian pakan tambahan untuk memperbaiki efisiensi reproduksi induk sapi. Jurnal Litbang Pertanian. 21: 19-2 

